\title{
Function of Axl receptor tyrosine kinase in non-small cell lung cancer (Review)
}

\author{
GUOAN ZHANG $^{1 *}$, MENG WANG $^{2 *}$, HONGLI ZHAO ${ }^{3}$ and WEN CUI ${ }^{1}$ \\ ${ }^{1}$ Cancer Pathology Research Institute, Jining Medical University, Jining, Shandong 272067; ${ }^{2}$ Department of Oncology, \\ Shandong Jining First People's Hospital, Jining, Shandong 272111; ${ }^{3}$ Department of Gastroenterology, \\ Shandong Control Center for Digestive Diseases, Jining, Shandong 272033, P.R. China
}

Received May 5, 2016; Accepted November 7, 2017

DOI: $10.3892 / \mathrm{ol} .2017 .7694$

\begin{abstract}
Axl receptor tyrosine kinase (hereafter Axl) is a member of the tyrosine-protein kinase receptor Tyro3, Axl and proto-oncogene tyrosine-protein kinase Mer family of receptor tyrosine kinases, possessing multiple different functions in normal cells. Axl is overexpressed and activated in numerous different human cancer types, triggering several signaling pathways and enhancing tumor progression. The present review assesses previous studies on the function of $\mathrm{Axl}$ in non-small cell lung cancer (NSCLC). Axl is overexpressed in the tumor tissues of a number of patients with NSCLC and is associated with poorer clinical outcomes; it promotes NSCLC tumor growth, invasion/metastasis, drug resistance and the epithelial-mesenchymal transition, thus providing a survival advantage to tumor cells. Therefore, Axl may be a promising target in NSCLC treatment.
\end{abstract}

\section{Contents}

1. Introduction

2. Axl activation and signaling

3. Function of Axl in NSCLC

4. Conclusion

\section{Introduction}

Axl receptor tyrosine kinase (hereafter Axl) is a member of the tyrosine-protein kinase receptor Tyro3 (hereafter

Correspondence to: Dr Wen Cui, Cancer Pathology Research Institute, Jining Medical University, 16 Beihu Road, Jining, Shandong 272067, P.R. China

E-mail: cuiwenmd@126.com

${ }^{*}$ Contributed equally

Key words: non-small cell lung cancer, Axl receptor tyrosine kinase, drug resistance, epithelial-mesenchymal transition, invasion, metastasis
Tyro3), Axl and proto-oncogene tyrosine-protein kinase Mer (hereafter Mer) (TAM) family of receptor tyrosine kinases (RTKs) (1). The TAM family is distinguished from other RTKs by a conserved sequence, $\mathrm{KW}(\mathrm{I} / \mathrm{L}) \mathrm{A}(\mathrm{I} / \mathrm{L}) \mathrm{ES}$, within the kinase domain and two immunoglobulin (Ig)-like domains plus two fibronectin type III domains, which comprise nearly the entire ectodomain of each family member $(1,2)$. In adult tissues, Tyro3, Axl and Mer are widely distributed (1), and have notable functions in tissue repair, clearance of apoptotic material and immune regulation (1,3-5). TAM receptors were initially considered to be orphan receptors (6); however, it has since been revealed that there are diverse ligands for this family of receptors (6-10). Growth arrest-specific 6 (Gas6) and protein $\mathrm{S}$ were identified to be ligands for TAMs in the 1990s $(6,7)$. These proteins are members of the vitamin $\mathrm{K}$-dependent protein family, and demonstrated significant homology with each other (8). Gas6 binds to all three TAM RTKs (Axl>Tyro3>Mer), whereas protein S interacts with Mer and Tyro3, but not Axl. Previously, tubby, tubby-like protein 1 (Tulp-1) and galectin-3 have been revealed to be ligands for TAM receptors, and Tulp-1 binds to all three RTKs with differing levels of affinity, whereas tubby only binds to $\operatorname{Mer}(9,10)$.

The name Axl is derived from the Greek word anexelekto, which means 'uncontrolled'. The human Axl gene is located on chromosome 19q13.2 and has 20 exons (11). It was originally identified as a transforming gene in the cells of patients with chronic myelogenous leukemia (12) and had transforming potential when overexpressed in NIH/3T3 fibroblasts $(13,14)$. As with other RTKs, Axl is composed of an extracellular domain, a transmembrane domain and an intracellular domain. A soluble Axl has also been reported (15), which may possess a diagnostic value for early-stage hepatocellular carcinoma (16). Axl is ubiquitously expressed in human tissues $(1,17)$, with notable levels identified in the kidney $(1,18)$, brain (19), heart (1), testis (1), skeletal muscle $(1)$, liver $(1,20)$, endothelial cells $(21,22)$, monocytes/macrophages (23) and platelets (24). This wide expression pattern of Axl indicates that this protein exerts a notable function in normal cell function, including cell survival, proliferation, migration and adhesion (17). However, usually, more than one TAM receptor is expressed in a given cell type simultaneously that may be activated by one common ligand; for example, all three TAM members may be activated 


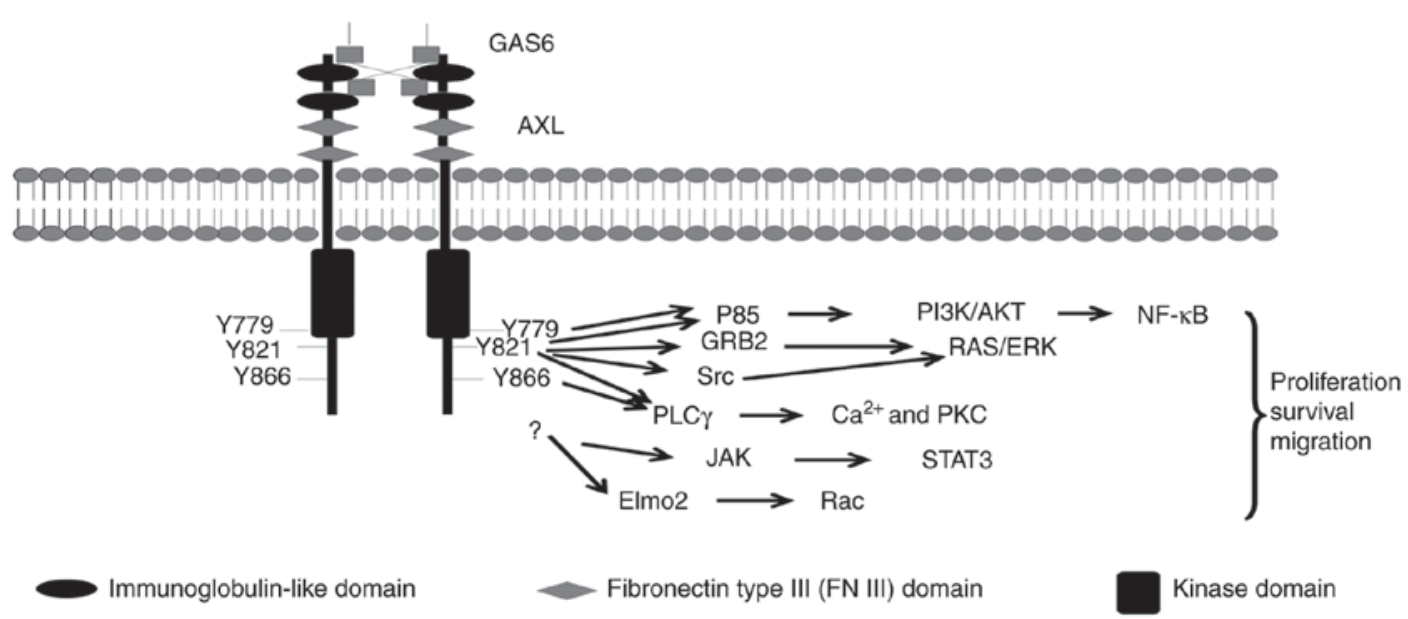

Figure 1. Schematic representation of the Axl signaling pathway. Activation of Axl by Gas6 binding results in the autophosphorylation of several tyrosine residues in the intracellular domain, including Y-779, Y-821 and Y-866, which provide docking sites for signaling proteins and consequently result in the activation of the PI3K/Akt pathway, RAS/ERK pathway, STAT3 pathway, NF-KB pathway, PLC $\gamma-\mathrm{Ca}^{2+} / \mathrm{PKC}$ pathway and Elmo2-Rac pathway, promoting tumor proliferation, survival and migration. The question mark represents the tyrosine sites responsible for JAK and Elmo2 activation remain unknown. Gas6, growth arrest-specific 6; PI3K, phosphoinositide 3-kinase; Akt, protein kinase B; ERK, extracellular signal-regulated kinase; STAT3, signal transducer

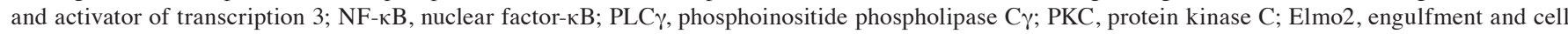
motility 2; JAK, Janus kinase.

by Gas6 (25), thus making it difficult to elucidate the function of Axl on its own in one cell type.

\section{Axl activation and signaling}

Axl is activated by Gas6. The activation of RTKs involves ligand binding to the extracellular domain, which induces receptor dimerization and subsequent trans-autophosphorylation of the tyrosine residues within the cytoplasmic domain (2). Axl is activated by the binding of its ligand Gas6, which was identified as the ligand for Axl in 1995 by two separate studies $(6,7)$. Prior to that, the Gas6 gene was first identified as one of several genes to be upregulated in NIH/3T3 fibroblasts under serum starvation-induced growth arrest (26). Gas6 was later revealed to be a common ligand for Axl, Tyro3 and Mer, with Axl possessing the highest affinity for Gas6 (3). Gas6 is widely expressed and has been identified in the lung, heart, kidney, intestine, endothelial cells, bone marrow, vascular smooth muscle cells and monocytes and at low levels in the liver and human blood plasma (27). It has cell-type-specific functions, including platelet aggregation and hematopoiesis, proliferation, survival and phagocytosis.

Gas 6 possesses an N-terminal region containing a modified $\gamma$-carboxyglutamic acid (Gla) residue, which has the ability to interact with negatively charged membrane phospholipids to mediate the binding of Gas6 to apoptotic cells. The Gla domain is followed by a loop region, four epidermal growth factor (EGF)-like repeats and a C-terminal sex-hormone-binding globulin (SHBG)-like structure that is composed of two globular laminin G-like domains (28). The SHBG domain binds directly to the Ig domains of Axl, which results in the formation of a Gas6/Axl complex with a 1:1 ratio (29). The lateral diffusion of these complexes would then result in the formation of a minimal 2:2 Gas6/Axl signaling complex, which induces activation of Axl (29). Additionally, the $\gamma$-carboxylation of Gas6 and anionic phospholipids, including the externalized phosphatidylserine on apoptotic cells and enveloped viruses, possesses vital functions for the activation of $\mathrm{Axl}(3,30,31)$.

Atypical activation of Axl. In addition to conventional activation, atypical activation of Axl has been reported, including activation by crosstalk between receptors (1). Meyer et al (32) revealed that EGF receptor (EGFR) activation associated with Axl and EGF stimulation may activate Axl through EGFR in triple-negative breast cancer cells. In non-small cell lung cancer (NSCLC), head and neck squamous cell carcinoma (HNSCC) $(33,34)$ and esophageal squamous cell carcinomas (ESCC) cells (34), this physical association between Axl and EGFR was also observed. This interaction has the potential to activate EGFR $(33,34)$ and Axl $(32,33)$. The ability of Axl to form complexes with other RTKs may make certain cancer types resistant to tyrosine kinase inhibitors (TKIs), as will be discussed further in the present review.

Three tyrosine residues, Y-779, Y-821 and Y-866, within the C-terminal domain of Axl have been proposed as potential autophosphorylation sites and putative docking sites for a variety of signaling proteins (1), including the p85a and p85b subunits of phosphatidylinositol 3-kinase (PI3K) $(35,36)$, growth factor receptor-bound protein $2(25,26)$, phospholipase $\mathrm{C} \gamma(\mathrm{PLC} \gamma)$ (36), c-src and lck (36) (Fig. 1). Additionally, the engulfment and cell motility (Elmo) scaffold protein has been reported to directly interact with Axl, and serves vital functions in Axl-induced breast cancer invasion (37). Notably, mutation of the three tyrosine residues did not abrogate the Axl-Elmo2 association, indicating that other docking sites may exist (37).

Activation of Axl regulates a number of signal transduction pathways, depending on the cell types in question, primarily $\mathrm{PI} 3 \mathrm{~K} /$ protein kinase $\mathrm{B}(\mathrm{Akt})$ and mitogen-activated protein kinase $(\mathrm{MEK}) /$ extracellular-signal-regulated kinase (ERK), nuclear factor $-\kappa \mathrm{B}(\mathrm{NF}-\kappa \mathrm{B})$, signal transducer and activator of transcription 3 (STAT3) $(17,38,39)$ [references $(1,3,17,40)$ contain further information on Axl signaling]. The activation of 


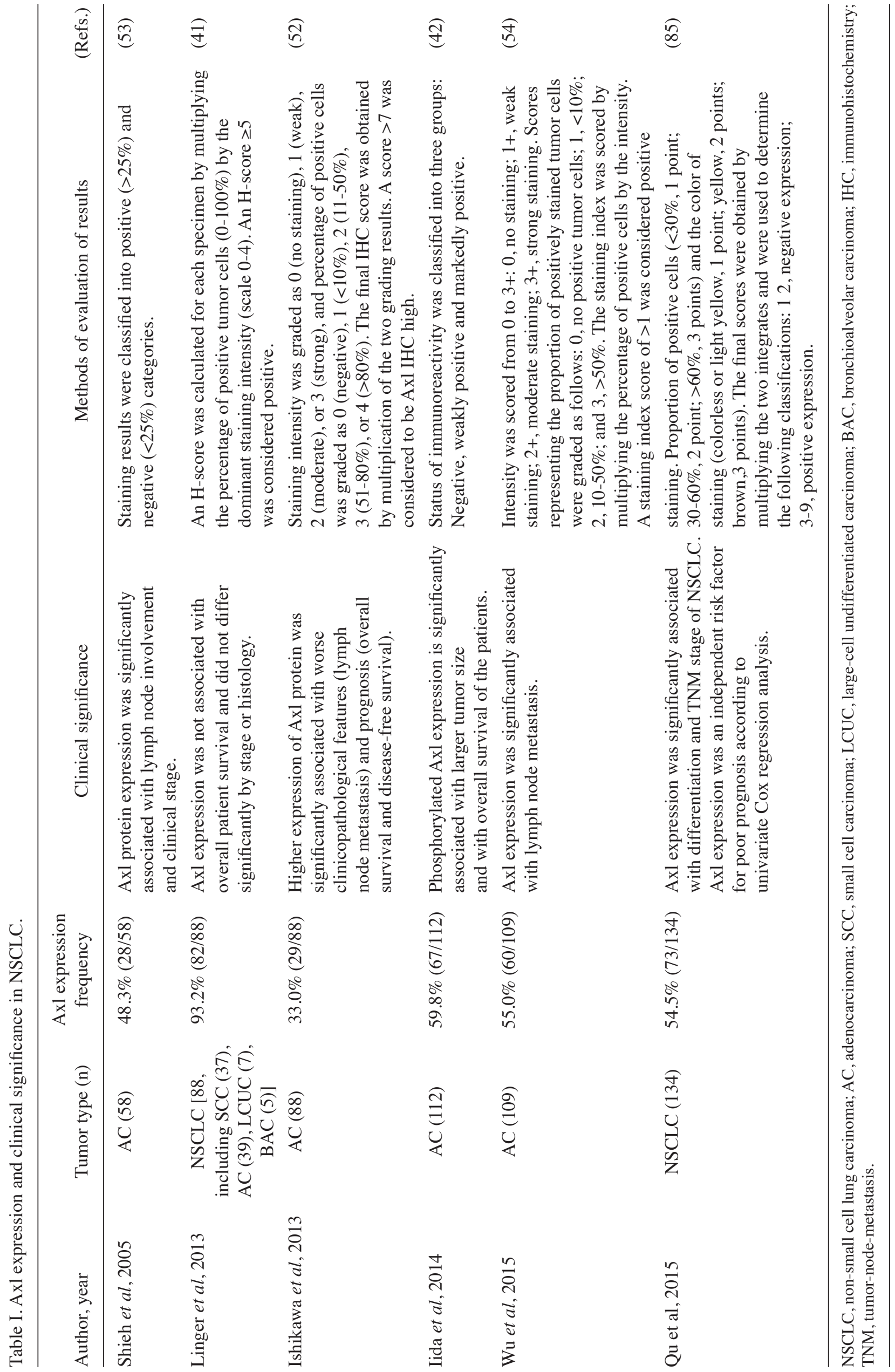


these pathways elicits different responses in different cells, including cell proliferation, migration or survival $(3,17)$ (Fig. 1).

\section{Function of Axl in NSCLC}

Axl is overexpressed in a subset of NSCLC, and is associated with poorer clinical outcomes. The expression of Axl and Gas6 in normal lung cells is not well documented. Studies aimed at detecting Axl expression in lung cancer cells demonstrated that Axl is not expressed in normal lung alveolar cells or the bronchial epithelium adjacent to a tumor $(41,42)$. Axl is expressed in lung airway macrophages, but not interstitial macrophages and other lung leukocytes under homeostatic conditions and is constitutively ligated to Gas6 (43). Axl was believed to serve notable functions in mediating immune homeostasis through the clearance of apoptotic cells during inflammation (43) and promoting an antiviral response through maintaining the appropriate production of type I interferon (44). Axl and Gas6 are also expressed in the blood endothelial cells of lung (45), in which they maintaining the integrity of the vasculature and vascular remodeling under pathological conditions (27).

Axl is expressed in NSCLC, with expression rates varying from $\sim 33.0$ to $\sim 93.2 \%$ detected by different groups (Table I). This inconsistency may be caused by different Axl antibodies used, and different evaluation methods. The varying clinicopathological characteristics of patients with NSCLC studied may also contribute to this inconsistence. These studies suggest a number of patients with NSCLC express Axl, and it may be associated with a poorer prognosis. Consistently, patients with NSCLC that exhibit high Axl mRNA expression had a shorter disease-free survival time than patients exhibiting low Axl mRNA expression (46).

Axl and tumor growth in NSCLC. Similar to other RTKs, Axl overexpression may provide survival and growth advantages to tumor cells (3). In NSCLC cell lines, the small interfering RNA (siRNA)-mediated downregulation of Axl results in decreased cell growth in vitro and in xenograft mouse models $(41,47)$, in addition to the suppression of Akt and ERK activation (34). Similarly, the proliferation of H226 cells, which express moderate levels of Axl, may be suppressed by the anti-Axl monoclonal antibody MAb173 or the specific Axl inhibitor R428 (33). These studies indicate that Axl is involved in maintaining the proliferation of NSCLC cells.

Axl and the epithelial-mesenchymal transition (EMT) in NSCLC. EMT is a process by which epithelial cells lose their cell polarity and cell-cell adhesion, and gain mesenchymal cell-like migratory and invasive properties (48). Axl is recognized as having vital functions in NSCLC EMT. Firstly, Axl is a marker for the mesenchymal phenotype in NSCLC. From the RNA-sequencing data of 643 cancer cell lines, including NSCLC, Axl expression was markedly associated with a mesenchymal phenotype (49). It was further revealed that in 45 NSCLC cell lines, higher Axl protein expression tends to be associated with a higher protein expression of vimentin, a mesenchymal marker (49). Similarly, Axl expression was higher in NSCLC mesenchymal cancer cells than in epithelial cancer cells, based on the mRNA expression profile of 54 NSCLC cell lines and the protein expression data of 49 patients with NSCLC (50).
Furthermore, in the transforming growth factor $\beta$-induced EMT model, Axl is upregulated, similar to vimentin (49). In addition, Axl aids the maintenance of the EMT state in NSCLC cells. A549 and H460 are mesenchymal NSCLC cells (50); in these cell lines, Axl downregulation results in the increased expression of E-cadherin and decreased expression of vimentin and $\mathrm{N}$-cadherin, which are features of the reverse of EMT (47).

Axl and NSCLC invasion and migration. Patients with cancer that have solid tumors primarily succumb to mortality due to metastatic lesions rather than from the primary tumors (51). Axl has been implicated in metastasis in multiple tumor types (3). In patients with NSCLC, Axl expression is associated with lymph node metastasis (52-54). Cisplatin- and gefitinib-resistant HCC4006 cells express high levels of Axl, and siRNA-mediated Axl downregulation suppressed the migratory capacity of these cells (55). Lay et al (56) established a series of cell lines with different invasive abilities by the selection of increasingly invasive cancer cell populations from a cell line of human lung adenocarcinoma (CL1-0) using a Transwell invasion chamber assay. It was revealed that Axl expression was highly associated with the migratory ability of these cell lines. NF- $\kappa \mathrm{B}$ signaling was responsible for Axl-enhanced migration, with its suppression blunting Axl-induced migration. Huang et al (57) additionally reported that Axl mediates $\mathrm{H}_{2} \mathrm{O}_{2}$-induced migration by activating PI3K/Akt/Ras-related $\mathrm{C} 3$ botulinum toxin substrate 1 signaling. Furthermore, the first Ig-like domain and the intracellular domain were vital for the function of Axl in these two models. These studies indicated that Axl may not only activate migration-promoting signals itself, but additionally mediate the effect of other molecules to increase migration. Mechanistically, Axl increases the expression of matrix metalloproteinase-9 (MMP9) and MMP2, which promote tissue remodeling and cancer invasion (58-61). Additionally, as discussed above, Axl promotes the EMT of cancer cells $(62,63)$, a process associated with migratory and invasive properties (48). Axl has also been associated with invasion through the modification of the cytoskeleton regulator Rac $(37,57,64)$, leading to cytoskeletal reorganization and increased migration and invasion.

Axl and cancer drug resistance in NSCLC. Drug resistance is the main reason for the failure of cancer treatments. Axl serves a notable function in the drug resistance of a number of different cancer types $(34,65-67)$; its function in NSCLC drug resistance has been studied intensively (68). Evidence is primarily derived from in vitro cell line studies (Table II), with limited data from mouse models $(33,69)$ and the tumor tissues of patients with cancer $(69,70)$ (Table III). Thus, these results may require further confirmation, particularly in human tumors in vivo.

The majority of cell line-based studies use drug-resistant cells, obtained by the long-term treatment of cancer cells with increasing doses of drugs, and such studies have revealed that Axl is upregulated in drug-resistant cancer cells (Table II). One study additionally revealed that suppression of Axl with genomic or pharmaceutical methods may restore the sensitivity of cancer cells to drugs, further informing on the function of Axl in these drug-resistant models (69). Other studies downregulated Axl expression in Axl-overexpressed NSCLC cancer 


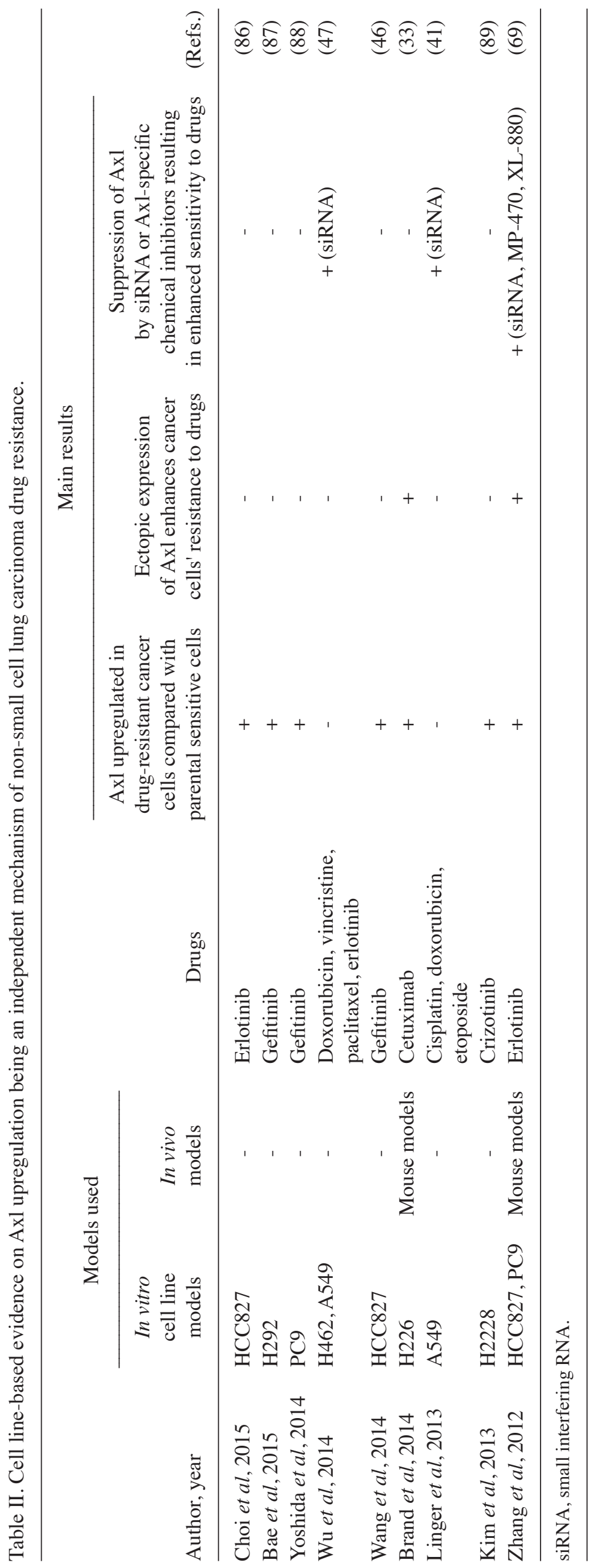


Table III. Patient tumor tissue-based evidence to demonstrate that Axl upregulation is an independent mechanism of NSCLC drug resistance.

\begin{tabular}{|c|c|c|c|c|}
\hline Author, year & Tumor tissues description & Patients, $\mathrm{n}$ & Main results & (Refs.) \\
\hline Zhang et al, 2012 & $\begin{array}{l}\text { Matched EGFR mutant NSCLC specimens } \\
\text { obtained prior to treatment with EGFR TKIs } \\
\text { erlotinib or gefitinib and following the } \\
\text { development of resistance to these } \\
\text { compounds. }\end{array}$ & 35 & $\begin{array}{l}\text { Compared with the treatment-native } \\
\text { tumor tissues, a higher expression } \\
\text { level of Axl and Gas6 were detected in } \\
7 / 35(20 \%) \text { and } 7 / 28(25 \%) \text { of } \\
\text { TKI-resistant tissues, respectively. }\end{array}$ & (69) \\
\hline Ji et al, 2013 & $\begin{array}{l}\text { Matched EGFR mutant NSCLC specimens } \\
\text { obtained prior to treatment with EGFR TKIs } \\
\text { erlotinib or gefitinib and following the } \\
\text { development of resistance to these compounds. }\end{array}$ & 26 & $\begin{array}{l}\text { Increased Axl expression was observed } \\
\text { in } 5 / 26(19.2 \%) \text { of patients with } \\
\text { TKI-resistant NSCLC. }\end{array}$ & (70) \\
\hline
\end{tabular}

NSCLC, non-small cell lung cancer; TKI, tyrosine kinase inhibitor; EGFR, epidermal growth factor receptor; Gas6, growth arrest-specific 6.

cells, including A549 and H462, to survey the change of the half maximal inhibitory concentration of cancer cells to drugs, and it was observed that the silencing of Axl enhanced the sensitivity of cancer cells to drugs, including several chemotherapeutic drugs and erlotinib $(41,47)$. Zhang et al (69) used a combination of strategies, including mouse models and matched NSCLC tumor tissues (tissues from the same patient prior to treatment and following the development of drug resistance), providing convincing evidence supporting the involvement of Axl in the mechanisms underlying NSCLC EGFR TKI resistance, and that targeting this molecule may restore the sensitivity of resistant cells. Similarly, Brand et al (33) used several differing strategies, including the ectopic overexpression of Axl, siRNA-mediated downregulation of Axl and mouse models, to demonstrate that Axl serves a notable function in NSCLC resistance to cetuximab, a chimeric monoclonal antibody targeting EGFR. In addition to the work of Zhang et al (69), Ji et al (70) provides further evidence using the tumor tissue of patients with NSCLC demonstrating that Axl upregulation is an independent mechanism of NSCLC resistance to EGFR-TKI (Table III).

A detailed mechanism for Axl-mediated drug resistance is yet to be elucidated. However, a number of studies have provided notable information. As previously discussed, the overexpression of Axl is linked to EMT status, which was associated with drug resistance $(71,72)$. Additionally, Axl impedes therapeutically induced apoptosis by exerting anti-apoptotic effects by modulating the expression or activation of apoptosis regulators, including B-cell lymphoma extra large, survivin (41), B-cell lymphoma-2 (Bcl-2) associated agonist of cell death (73), Bh3 interacting-domain death agonist (74) and Bcl-2 (75). Additionally, a number of previous studies have suggested that the ability of Axl to form complexes with other RTKs may be one key aspect of this function. Cetuximab-resistant NSCLC cell line H226 cells exhibited upregulation of Axl signaling, which was further elucidated to form a physical complex with EGFR (33). Furthermore, treatment with EGF or tumor necrosis factor resulted in $\mathrm{H} 226$ cells resistant to cetuximab, with the formation of a physical complex between Axl and EGFR, similar to that in resistant cells. This indicates that the Axl-EGFR complex serves a role in eliciting a drug-resistant phenotype of cancer cells. These studies further demonstrated that Axl and EGFR were involved in maintaining the growth of these resistant cells. Additionally, silencing the expression of either Axl or EGFR with siRNA decreased the growth of these cells. The Axl-EGFR complex was also observed in other drug resistant cancer models. For example, as mentioned above, HNSCC and ESCC cells induced to be resistant to PI3K inhibitor BYL719 additionally displayed this Axl-EGFR complex (34). In sensitive parental cells, EGFR activated the PI3K/Akt pathway, which maintained mechanistic target of rapamycin (mTOR) activity (76). In resistant cells, the Axl-EGFR complex activated PLC $\gamma$-protein kinase C (PKC) signaling, which in turn activated mTOR (76). Thus, tumor cells became less dependent on PI3K/Akt signaling and resistant to PI3K inhibitor BYL719. Combining BYL719 and R428 may reverse the resistant phenotype. This complex additionally formed in breast cancer cells, and Axl in this complex amplified and diversified EGFR signaling (32). Thus, it may be that this complex increased the resistance of cancer cells to EGFR inhibitors and that the suppression of Axl may enhance the efficacy of EGFR inhibitors. Further studies revealed that the suppression of Axl activation with R428 significantly increased the killing ability of erlotinib (32). Furthermore, Wu et al (54) revealed that Axl and EGFR are co-expressed in a subset of NSCLC tumor tissues. This may allow this complex to form readily, promoting drug resistance. Other receptors, including human epidermal growth factor receptor 2 (HER2), HER3, MET proto-oncogene and platelet-derived growth factor receptor- $\beta$ have been reported to be associated with Axl (32). This association of Axl with other receptors may have implications for targeted therapies, as these complexes may change the response of RTKs to TKIs, or make cancer cells less dependent on the signaling pathways that were targeted (34), which may result in cancer cells resistant to TKIs.

There are additional reports indicating a minimal function of Axl in the resistance of NSCLCs to TKIs.Forexample, the suppression of Axl with siRNA or chemical inhibitors in erlotinib-resistant H358 (77) and HCC827 (49) cells, which demonstrated an increased expression of Axl, could not restore the sensitivity of the cells to drug treatment. 


\section{Conclusion}

Axl is a promising therapeutic target, considering that it serves notable functions in NSCLC tumor growth, EMT, invasion and drug resistance. A number of Axl inhibitors have been developed and a number are in clinical trials, including foretinib (XL880, GSK1363089), cabozantinib, crizotinib, ASLAN002 and BGB324 (R428) (3,78-81). It is important to note that although a wide range of Axl kinase inhibitors have been described, a majority of them are nonspecific multi-kinase inhibitors. BGB324 (R428) was the first selective Axl inhibitor to be developed (82). Oral treatment with BGB324 (R428) in mouse xenograft models revealed that it reduced breast cancer metastasis and prolonged survival. It entered phase 1 clinical trials in 2013 (83). At present, clinical trials including patients with melanoma, NSCLC and acute myeloid leukemia are ongoing to determine the safety and efficiency of BGB324 (https://clinicaltrials.gov/ct2/results?cond=\&term=BGB324\&cntryl=\&state1= $\&$ Search=Search). The identification of appropriate biomarkers for the selection of patients is another key issue for the development of Axl-targeted therapies. Immunohistochemistry appears to be the most feasible strategy for identifying appropriate biomarkers, with other strategies including the detection of Axl expression in vivo by single-photon emission computed tomography imaging using a ${ }^{125}$ I-labled Axl antibody (84). With the development of AXL inhibitors, and an increase in the understanding of the underlying molecular mechanisms responsible for NSCLC, patients who are suitable for AXL-targeted therapies could be screened and treated with this form of therapy.

\section{Acknowledgements}

The present review was supported by the Project of Shandong Province Higher Educational Science and Technology Program (grant no. J13LK14).

\section{References}

1. Linger RM, Keating AK, Earp HS and Graham DK: TAM receptor tyrosine kinases: Biologic functions, signaling, and potential therapeutic targeting in human cancer. Adv Cancer Res 100: 35-83, 2008.

2. Lemmon MA and Schlessinger J: Cell signaling by receptor tyrosine kinases. Cell 141: 1117-1134, 2010.

3. Graham DK, DeRyckere D, Davies KD and Earp HS: The TAM family: Phosphatidylserine sensing receptor tyrosine kinases gone awry in cancer. Nat Rev Cancer 14: 769-785, 2014

4. Rothlin CV, Carrera-Silva EA, Bosurgi L and Ghosh S: TAM receptor signaling in immune homeostasis. Annu Rev Immunol 33: 355-391, 2015.

5. Lemke G and Rothlin CV: Immunobiology of the TAM receptors. Nat Rev Immunol 8: 327-336, 2008.

6. Stitt TN, Conn G, Gore M, Lai C, Bruno J, Radziejewski C, Mattsson K, Fisher J, Gies DR, Jones PF, et al: The anticoagulation factor protein $\mathrm{S}$ and its relative, Gas6, are ligands for the Tyro 3/Axl family of receptor tyrosine kinases. Cell 80: 661-670, 1995.

7. Varnum BC, Young C, Elliott G, Garcia A, Bartley TD, Fridell YW, Hunt RW, Trail G, Clogston C, Toso RJ, et al: Axl receptor tyrosine kinase stimulated by the vitamin K-dependent protein encoded by growth-arrest-specific gene 6 . Nature 373: 623-626, 1995.

8. Manfioletti G, Brancolini C, Avanzi G and Schneider C: The protein encoded by a growth arrest-specific gene (gas6) is a new member of the vitamin K-dependent proteins related to protein $\mathrm{S}$, a negative coregulator in the blood coagulation cascade. Mol Cell Biol 13: 4976-4985, 1993
9. Caberoy NB, Alvarado G, Bigcas JL and Li W: Galectin-3 is a new MerTK-specific eat-me signal. J Cell Physiol 227: 401-407, 2012.

10. Caberoy NB, Zhou Y and Li W: Tubby and tubby-like protein 1 are new MerTK ligands for phagocytosis. EMBO J 29: 3898-3910, 2010.

11. Verma A, Warner SL, Vankayalapati H, Bearss DJ and Sharma S: Targeting Axl and Mer kinases in cancer. Mol Cancer Ther 10: 1763-1773, 2011.

12. Liu E, Hjelle B and Bishop JM: Transforming genes in chronic myelogenous leukemia. Proc Natl Acad Sci USA 85: 1952-1956, 1988.

13. O'Bryan JP, Frye RA, Cogswell PC, Neubauer A, Kitch B, Prokop C, Espinosa R III, Le Beau MM, Earp HS and Liu ET: axl, a transforming gene isolated from primary human myeloid leukemia cells, encodes a novel receptor tyrosine kinase. Mol Cell Biol 11: 5016-5031, 1991.

14. Janssen JW, Schulz AS, Steenvoorden AC, Schmidberger M, Strehl S, Ambros PF and Bartram CR: A novel putative tyrosine kinase receptor with oncogenic potential. Oncogene 6: 2113-2120, 1991.

15. O'Bryan JP, Fridell YW, Koski R, Varnum B and Liu ET: The transforming receptor tyrosine kinase, Axl, is post-translationally regulated by proteolytic cleavage. J Biol Chem 270: 551-557, 1995.

16. Reichl P, Fang M, Starlinger P, Staufer K, Nenutil R, Muller P, Greplova K, Valik D, Dooley S, Brostjan C, et al: Multicenter analysis of soluble Axl reveals diagnostic value for very early stage hepatocellular carcinoma. Int J Cancer 137: 385-394, 2015.

17. Hafizi S and Dahlbäck B: Signalling and functional diversity within the Axl subfamily of receptor tyrosine kinases. Cytokine Growth Factor Rev 17: 295-304, 2006.

18. Chung BI, Malkowicz SB, Nguyen TB, Libertino JA and McGarvey TW: Expression of the proto-oncogene Axl in renal cell carcinoma. DNA Cell Biol 22: 533-540, 2003.

19. Prieto AL, Weber JL and Lai C: Expression of the receptor protein-tyrosine kinases Tyro-3, Axl, and mer in the developing rat central nervous system. J Comp Neurol 425: 295-314, 2000.

20. Lafdil F, Chobert MN, Couchie D, Brouillet A, Zafrani ES, Mavier P and Laperche Y: Induction of Gas6 protein in CCl4-induced rat liver injury and anti-apoptotic effect on hepatic stellate cells. Hepatology 44: 228-239, 2006.

21. Melaragno MG, Fridell YW and Berk BC: The Gas6/Axl system: A novel regulator of vascular cell function. Trends Cardiovasc Med 9: 250-253, 1999.

22. Ruan GX and Kazlauskas A: Axl is essential for VEGF-A-dependent activation of PI3K/Akt. EMBO J 31: 1692-1703, 2012.

23. Neubauer A, Fiebeler A, Graham DK, O'Bryan JP, Schmidt CA, Barckow P, Serke S, Siegert W, Snodgrass HR, Huhn D, et al: Expression of axl, a transforming receptor tyrosine kinase, in normal and malignant hematopoiesis. Blood 84: 1931-1941, 1994.

24. Angelillo-Scherrer A, de Frutos P, Aparicio C, Melis E, Savi P, Lupu F, Arnout J, Dewerchin M, Hoylaerts M, Herbert J, et al: Deficiency or inhibition of Gas6 causes platelet dysfunction and protects mice against thrombosis. Nat Med 7: 215-221, 2001.

25. Nagata K, Ohashi K, Nakano T, Arita H, Zong C, Hanafusa $\mathrm{H}$ and Mizuno K: Identification of the product of growth arrest-specific gene 6 as a common ligand for Axl, Sky, and Mer receptor tyrosine kinases. J Biol Chem 271: 30022-30027, 1996.

26. Schneider C, King RM and Philipson L: Genes specifically expressed at growth arrest of mammalian cells. Cell 54: 787-793, 1988.

27. Laurance S, Lemarié CA and Blostein MD: Growth Arrest-specific gene 6 (gas6) and vascular hemostasis. Adv Nutr 3: 196-203, 2012.

28. Hafizi S and Dahlbäck B: Gas6 and protein S. Vitamin K-dependent ligands for the Axl receptor tyrosine kinase subfamily. FEBS J 273: 5231-5244, 2006.

29. Sasaki T, Knyazev PG, Clout NJ, Cheburkin Y, Göhring W, Ullrich A, Timpl R and Hohenester E: Structural basis for Gas6-Axl signalling. EMBO J 25: 80-87, 2006.

30. Tsou WI, Nguyen KQ, Calarese DA, Garforth SJ, Antes AL, Smirnov SV, Almo SC, Birge RB and Kotenko SV: Receptor tyrosine kinases, TYRO3, AXL, and MER, demonstrate distinct patterns and complex regulation of ligand-induced activation. J Biol Chem 289: 25750-25763, 2014.

31. Lew ED, Oh J, Burrola PG, Lax I, Zagórska A, Través PG, Schlessinger $J$ and Lemke G: Differential TAM receptor-ligand-phospholipid interactions delimit differential TAM bioactivities. Elife 3, 2014 
32. Meyer AS, Miller MA, Gertler FB and Lauffenburger DA: The receptor AXL diversifies EGFR signaling and limits the response to EGFR-targeted inhibitors in triple-negative breast cancer cells. Sci Signal 6: ra66, 2013.

33. Brand TM, Iida M, Stein AP, Corrigan KL, Braverman CM, Luthar N, Toulany M, Gill PS, Salgia R, Kimple RJ and Wheeler DL: AXL mediates resistance to cetuximab therapy. Cancer Res 74: 5152-5164, 2014.

34. Elkabets M, Pazarentzos E, Juric D, Sheng Q, Pelossof RA, Brook S, Benzaken AO, Rodon J, Morse N, Yan JJ, et al: AXL mediates resistance to $\mathrm{PI} 3 \mathrm{~K} \alpha$ inhibition by activating the EGFR/PKC/mTOR axis in head and neck and esophageal squamous cell carcinomas. Cancer Cell 27: 533-546, 2015.

35. Fridell YW, Jin Y, Quilliam LA, Burchert A, McCloskey P, Spizz G, Varnum B, Der C and Liu ET: Differential activation of the Ras/extracellular-signal-regulated protein kinase pathway is responsible for the biological consequences induced by the Axl receptor tyrosine kinase. Mol Cell Biol 16: 135-145, 1996.

36. Braunger J, Schleithoff L, Schulz AS, Kessler H, Lammers R, Ullrich A, Bartram CR and Janssen JW: Intracellular signaling of the Ufo/Axl receptor tyrosine kinase is mediated mainly by a multi-substrate docking-site. Oncogene 14: 2619-2631, 1997.

37. Abu-Thuraia A, Gauthier R, Chidiac R, Fukui Y, Screaton RA Gratton JP and Côté JF: Axl phosphorylates elmo scaffold proteins to promote Rac activation and cell invasion. Mol Cell Biol 35: 76-87, 2015.

38. Linger RM, Keating AK, Earp HS and Graham DK: Taking aim at Mer and Axl receptor tyrosine kinases as novel therapeutic targets in solid tumors. Expert Opin Ther Targets 14: 1073-1090, 2010.

39. Yanagita M, Arai H, Nakano T, Ohashi K, Mizuno K, Fukatsu A, Doi T and Kita T: Gas6 induces mesangial cell proliferation via latent transcription factor STAT3. J Biol Chem 276: 42364-42369, 2001.

40. Brandão L, Migdall-Wilson J, Eisenman K and Graham DK: TAM receptors in leukemia: Expression, signaling, and therapeutic implications. Crit Rev Oncog 16: 47-63, 2011.

41. Linger RM, Cohen RA, Cummings CT, Sather S, Migdall-Wilson J, Middleton DH, Lu X, Barón AE, Franklin WA, Merrick DT, et al: Mer or Axl receptor tyrosine kinase inhibition promotes apoptosis, blocks growth and enhances chemosensitivity of human non-small cell lung cancer. Oncogene 32: 3420-3431, 2013.

42. Iida S, Miki Y, Suzuki T, Mori K, Saito M, Niikawa H, Kondo T, Yamada-Okabe $\mathrm{H}$ and Sasano $\mathrm{H}$ : Activation of AXL and antitumor effects of a monoclonal antibody to AXL in lung adenocarcinoma. Anticancer Res 34: 1821-1827, 2014.

43. Fujimori T, Grabiec AM, Kaur M, Bell TJ, Fujino N, Cook PC, Svedberg FR, MacDonald AS, Maciewicz RA, Singh D and Hussell T: The Axl receptor tyrosine kinase is a discriminator of macrophage function in the inflamed lung. Mucosal Immunol 8 : 1021-1030, 2015

44. Schmid ET, Pang IK, Carrera Silva EA, Bosurgi L, Miner JJ, Diamond MS, Iwasaki A and Rothlin CV: AXL receptor tyrosine kinase is required for $\mathrm{T}$ cell priming and antiviral immunity. Elife 5: pii: e12414, 2016.

45. Healy AM, Schwartz JJ, Zhu X, Herrick BE, Varnum B and Farber HW: Gas 6 promotes Axl-mediated survival in pulmonary endothelial cells. Am J Physiol Lung Cell Mol Physiol 280: L1273-L1281, 2001.

46. Wang Y, Xia H, Zhuang Z, Miao L, Chen X and Cai H: Axl-altered microRNAs regulate tumorigenicity and gefitinib resistance in lung cancer. Cell Death Dis 5: e1227, 2014.

47. Wu F, Li J, Jang C, Wang J and Xiong J: The role of Axl in drug resistance and epithelial-to-mesenchymal transition of non-small cell lung carcinoma. Int J Clin Exp Pathol 7: 6653-6661, 2014.

48. Thiery JP, Acloque H, Huang RY and Nieto MA: Epithelial-mesenchymal transitions in development and disease. Cell 139: 871-890, 2009.

49. Wilson C, Ye X, Pham T, Lin E, Chan S, McNamara E, Neve RM, Belmont L, Koeppen H, Yauch RL, et al: AXL inhibition sensitizes mesenchymal cancer cells to antimitotic drugs. Cancer Res 74: 5878-5890, 2014

50. Byers LA, Diao L, Wang J, Saintigny P, Girard L, Peyton M, Shen L, Fan Y, Giri U, Tumula PK, et al: An epithelial-mesenchymal transition gene signature predicts resistance to EGFR and PI3K inhibitors and identifies Axl as a therapeutic target for overcoming EGFR inhibitor resistance. Clin Cancer Res 19: $279-290,2013$
51. Hanahan D and Weinberg RA: The hallmarks of cancer. Cell 100 $57-70,2000$.

52. Ishikawa M, Sonobe M, Nakayama E, Kobayashi M, Kikuchi R, Kitamura J, Imamura N and Date H: Higher expression of receptor tyrosine kinase Axl, and differential expression of its ligand, Gas6, predict poor survival in lung adenocarcinoma patients. Ann Surg Oncol 20 (Suppl 3): S467-S476, 2013.

53. Shieh YS, Lai CY, Kao YR, Shiah SG, Chu YW, Lee HS and Wu CW: Expression of axl in lung adenocarcinoma and correlation with tumor progression. Neoplasia 7: 1058-1064, 2005.

54. Wu Z, Bai F, Fan L, Pang W, Han R, Wang J, Liu Y, Yan X, Duan $\mathrm{H}$ and Xing L: Coexpression of receptor tyrosine kinase AXL and EGFR in human primary lung adenocarcinomas. Hum Pathol 46: 1935-1944, 2015.

55. Kurokawa M,Ise N,Omi K, Goishi K and Higashiyama S: Cisplatin influences acquisition of resistance to molecular-targeted agents through epithelial-mesenchymal transition-like changes. Cancer Sci 104: 904-911, 2013.

56. Lay JD, Hong CC, Huang JS, Yang YY, Pao CY, Liu CH, Lai YP, Lai GM, Cheng AL, Su IJ and Chuang SE: Sulfasalazine suppresses drug resistance and invasiveness of lung adenocarcinoma cells expressing AXL. Cancer Res 67: 3878-3887, 2007.

57. Huang JS, Cho CY, Hong CC, Yan MD, Hsieh MC, Lay JD, Lai GM, Cheng AL and Chuang SE: Oxidative stress enhances AXL-mediated cell migration through AKT1/Racl-dependent mechanism. Free Radic Biol Med 65: 1246-1256, 2013.

58. Tai KY, Shieh YS, Lee CS, Shiah SG and Wu CW: Axl promotes cell invasion by inducing MMP-9 activity through activation of NF-kappaB and Brg-1. Oncogene 27: 4044-4055, 2008.

59. Reichl P, Dengler M, van Zijl F, Huber H, Führlinger G, Reichel C, Sieghart W, Peck-Radosavljevic M, Grubinger M and Mikulits W: Axl activates autocrine transforming growth factor- $\beta$ signaling in hepatocellular carcinoma. Hepatology 61: 930-941, 2015.

60. Chiu KC, Lee CH, Liu SY, Yeh CT, Huang RY, Yuh DY, Cheng JC, Chou YT and Shieh YS: Protumoral effect of macrophage through Axl activation on mucoepidermoid carcinoma. J Oral Pathol Med 43: 538-544, 2014.

61. Han J, Tian R, Yong B, Luo C, Tan P, Shen J and Peng T: Gas6/Axl mediates tumor cell apoptosis, migration and invasion and predicts the clinical outcome of osteosarcoma patients. Biochem Biophys Res Commun 435: 493-500, 2013.

62. Asiedu MK, Beauchamp-Perez FD, Ingle JN, Behrens MD, Radisky DC and Knutson KL: AXL induces epithelial-to-mesenchymal transition and regulates the function of breast cancer stem cells. Oncogene 33: 1316-1324, 2014

63. Cheng P, Phillips E, Kim SH, Taylor D, Hielscher T, Puccio L, Hjelmeland AB, Lichter P, Nakano I and Goidts V: Kinome-wide shRNA screen identifies the receptor tyrosine kinase AXL as a key regulator for mesenchymal glioblastoma stem-like cells. Stem Cell Reports 4: 899-913, 2015.

64. Allen MP, Linseman DA, Udo H, Xu M, Schaack JB, Varnum B, Kandel ER, Heidenreich KA and Wierman ME: Novel mechanism for gonadotropin-releasing hormone neuronal migration involving Gas6/Ark signaling to p38 mitogen-activated protein kinase. Mol Cell Biol 22: 599-613, 2002.

65. Mahadevan D, Cooke L, Riley C, Swart R, Simons B, Della Croce K, Wisner L, Iorio M, Shakalya K, Garewal H, et al: A novel tyrosine kinase switch is a mechanism of imatinib resistance in gastrointestinal stromal tumors. Oncogene 26: 3909-3919, 2007

66. Giles KM, Kalinowski FC, Candy PA, Epis MR, Zhang PM, Redfern AD, Stuart LM, Goodall GJ and Leedman PJ: Axl mediates acquired resistance of head and neck cancer cells to the epidermal growth factor receptor inhibitor erlotinib. Mol Cancer Ther 12: 2541-2558, 2013

67. Liu L, Greger J, Shi H, Liu Y, Greshock J, Annan R, Halsey W, Sathe GM, Martin AM and Gilmer TM: Novel mechanism of lapatinib resistance in HER2-positive breast tumor cells: Activation of AXL. Cancer Res 69: 6871-6878, 2009.

68. Paccez JD, Vogelsang M, Parker MI and Zerbini LF: The receptor tyrosine kinase Axl in cancer: Biological functions and therapeutic implications. Int J Cancer 134: 1024-1033, 2014.

69. Zhang Z, Lee JC, Lin L, Olivas V, Au V, LaFramboise T, Abdel-Rahman M, Wang X, Levine AD, Rho JK, et al: Activation of the AXL kinase causes resistance to EGFR-targeted therapy in lung cancer. Nat Genet 44: 852-860, 2012

70. Ji W, Choi CM, Rho JK, Jang SJ, Park YS, Chun SM, Kim WS, Lee JS, Kim SW, Lee DH and Lee JC: Mechanisms of acquired resistance to EGFR-tyrosine kinase inhibitor in Korean patients with lung cancer. BMC Cancer 13: 606, 2013. 
71. Zheng X, Carstens JL, Kim J, Scheible M, Kaye J, Sugimoto H, Wu CC, LeBleu VS and Kalluri R: Epithelial-to-mesenchymal transition is dispensable for metastasis but induces chemoresistance in pancreatic cancer. Nature 527: 525-530, 2015.

72. Fischer KR, Durrans A, Lee S, Sheng J, Li F, Wong ST, Choi H, El Rayes T, Ryu S, Troeger J, et al: Epithelial-to-mesenchymal transition is not required for lung metastasis but contributes to chemoresistance. Nature 527: 472-476, 2015.

73. Lee WP, Wen Y, Varnum B and Hung MC: Akt is required for Axl-Gas6 signaling to protect cells from E1A-mediated apoptosis. Oncogene 21: 329-336, 2002.

74. Papadakis ES, Cichoń MA, Vyas JJ, Patel N, Ghali L, Cerio R, Storey A and O'Toole EA: Axl promotes cutaneous squamous cell carcinoma survival through negative regulation of pro-apoptotic Bcl-2 family members. J Invest Dermatol 131: 509-517, 2011.

75. Hong CC, Lay JD, Huang JS, Cheng AL, Tang JL, Lin MT, Lai GM and Chuang SE: Receptor tyrosine kinase AXL is induced by chemotherapy drugs and overexpression of AXL confers drug resistance in acute myeloid leukemia. Cancer Lett 268: 314-324, 2008.

76. Meric-Bernstam F and Gonzalez-Angulo AM: Targeting the mTOR signaling network for cancer therapy. J Clin Oncol 27: 2278-2287, 2009.

77. Suda K, Mizuuchi H, Sato K, Takemoto T, Iwasaki T and Mitsudomi T: The insulin-like growth factor 1 receptor causes acquired resistance to erlotinib in lung cancer cells with the wild-type epidermal growth factor receptor. Int J Cancer 135: 1002-1006, 2014.

78. Myers SH, Brunton VG and Unciti-Broceta A: AXL inhibitors in cancer: A medicinal chemistry perspective. J Med Chem 59: 3593-3608, 2016.

79. Feneyrolles C, Spenlinhauer A, Guiet L, Fauvel B, Daydé-Cazals B, Warnault P, Chevé G and Yasri A: Axl kinase as a key target for oncology: Focus on small molecule inhibitors. Mol Cancer Ther 13: 2141-2148, 2014

80. Levin PA, Brekken RA, Byers LA, Heymach JV and Gerber DE: Axl receptor axis: A new therapeutic target in lung cancer. J Thorac Oncol 11: 1357-1362, 2016.
81. Wu X, Liu X, Koul S, Lee CY, Zhang Z and Halmos B: AXL kinase as a novel target for cancer therapy. Oncotarget 5: 9546-9563, 2014

82. Holland SJ, Pan A, Franci C, Hu Y, Chang B, Li W, Duan M, Torneros A, Yu J, Heckrodt TJ, et al: R428, a selective small molecule inhibitor of Axl kinase, blocks tumor spread and prolongs survival in models of metastatic breast cancer. Cancer Res 70: 1544-1554, 2010.

83. Sheridan C: First Axl inhibitor enters clinical trials. Nat Biotechnol 31: 775-776, 2013.

84. Nimmagadda S, Pullambhatla M, Lisok A, Hu C, Maitra A and Pomper MG: Imaging Axl expression in pancreatic and prostate cancer xenografts. Biochem Biophys Res Commun 443: 635-640, 2014.

85. Qu XH, Liu JL, Zhong XW, Li XI and Zhang QG: Insights into the roles of hnRNP A2/B1 and AXL in non-small cell lung cancer. Oncol Lett 10: 1677-1685, 2015.

86. Choi YJ, Kim SY, So KS, Baek IJ, Kim WS, Choi SH, Lee JC, Bivona TG, Rho JK and Choi CM: AUY922 effectively overcomes MET- and AXL-mediated resistance to EGFR-TKI in lung cancer cells. PLoS One 10: e0119832, 2015.

87. Bae SY, Hong JY, Lee HJ, Park HJ and Lee SK: Targeting the degradation of AXL receptor tyrosine kinase to overcome resistance in gefitinib-resistant non-small cell lung cancer. Oncotarget 6: 10146-10160, 2015.

88. Yoshida T, Zhang G, Smith MA, Lopez AS, Bai Y, Li J, Fang B, Koomen J, Rawal B, Fisher KJ, et al: Tyrosine phosphoproteomics identifies both codrivers and cotargeting strategies for T790M-related EGFR-TKI resistance in non-small cell lung cancer. Clin Cancer Res 20: 4059-4074, 2014.

89. Kim HR, Kim WS, Choi YJ, Choi CM, Rho JK and Lee JC: Epithelial-mesenchymal transition leads to crizotinib resistance in H2228 lung cancer cells with EML4-ALK translocation. Mol Oncol 7: 1093-1102, 2013. 